\title{
Deletion of chromosome 2 (p11-p13): case report and review
}

\author{
V P Prasher, V H R Krishnan, D J Clarke, C T Maliszewska, J A Corbett
}

\begin{abstract}
The case of a young man with del(2) (p11.2p13) is reported. Accounts of previous cases of deletion of the short arm of chromosome 2 are reviewed. Common features include mental retardation, proportional short stature and weight, dysmorphic facial features (a prominent nose, abnormal ears), and abnormal hands. Growth and developmental delay are present during the postnatal period. (f Med Genet 1993;30:604-6)
\end{abstract}

Structural deletions of the short arm of chromosome 2 alone are rare and only eight cases have previously been reported. FergusonSmith et $a l^{1}$ were the first to report a patient with a deletion of the short arm of chromosome 2 . This case was also associated with partial duplication of chromosome 5. Later Zackai $e t a l^{2}$ reported a case with a monosomy $2 p$ deletion. The description of the phenotype was limited, although further details of the patient were subsequently given by Emanuel et $a l^{3}$ and Neidich et $a l .{ }^{4}$ Other cases of $\operatorname{del}(2 p)$ have subsequently been reported.

The case of a 32 year old man with karyotype $\operatorname{del}(2)(\mathrm{p} 11 \mathrm{p} 13)$ is reported and two other previous case reports of $\operatorname{del}(2 \mathrm{p})$, by Fryns et $a l^{5}$ and Duca $e t$ al, ${ }^{6}$ involving the proximal region are reviewed.

\section{Case report}

The proband, a 32 year old Caucasian male, is a long term resident of a hospital for the mentally handicapped. He was admitted in 1978 at the age of 19 years. Little is known about his birth because he was taken into care by the local social service department soon after the event. Developmental milestones were delayed; he was unable to walk at the age of $2 \frac{1}{2}$ years, made babbling sounds at 2 years, and had poor feeding skills at 3 years. At the age of 5 years his intelligence quotient (IQ) was between 37 and 40 on the Terman-Merrill scale. His early life was spent in different social services' residential settings but because of his mental handicap and behavioural difficulties he was admitted to a hospital for children with mental handicap at the age of 7 years. Reassessment of his intellectual functioning using the Wechsler Intelligence for Children scale gave a verbal IQ score below 45 and a performance score below 44 .

During the next six years, with consistent care, gradual improvement occurred in his behaviour. At the age of 13 years he was transferred to a community children's home and there were no major difficulties until the age of 18 years when he began to steal money and other valuable items. He was also verbally abusive and physically aggressive. Neuroleptic medication was of minimal benefit, and he was admitted to the hospital when fire setting became a problem.

Since his admission to the hospital, his antisocial behaviour has been difficult to control and there have been numerous incidents of aggression, theft, and other behavioural problems. Neuroleptic medication along with a behavioural approach has had little long term benefit.

At the age of 32 years his weight is $70 \mathrm{~kg}$ $(>50$ th centile), height $180 \mathrm{~cm}(>50$ th centile), and head circumference $53 \mathrm{~cm}(<25$ th centile). On examination he is a tall, thin man
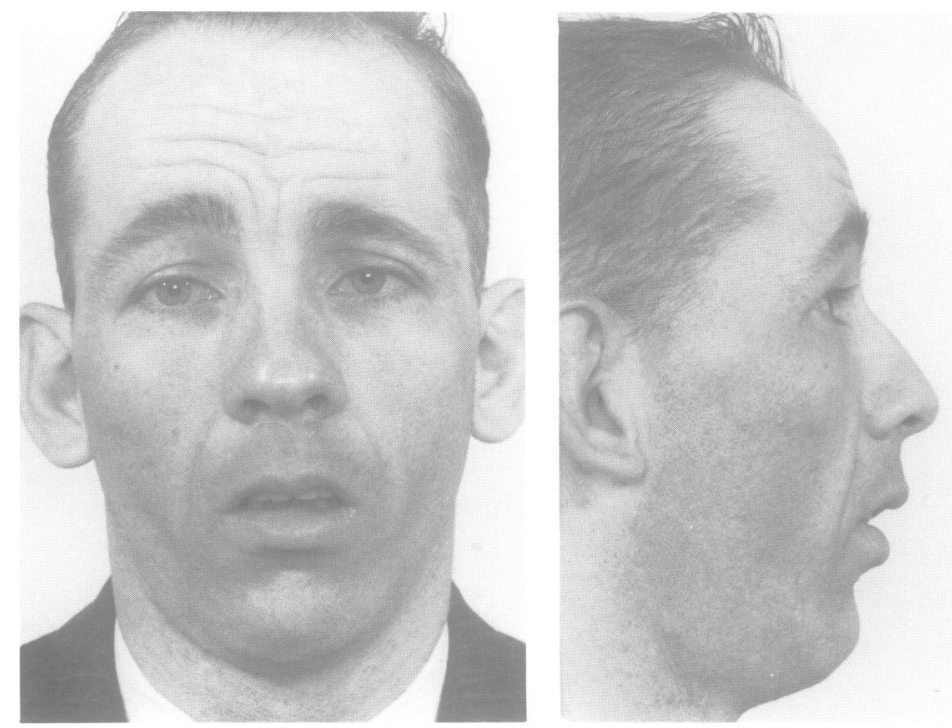


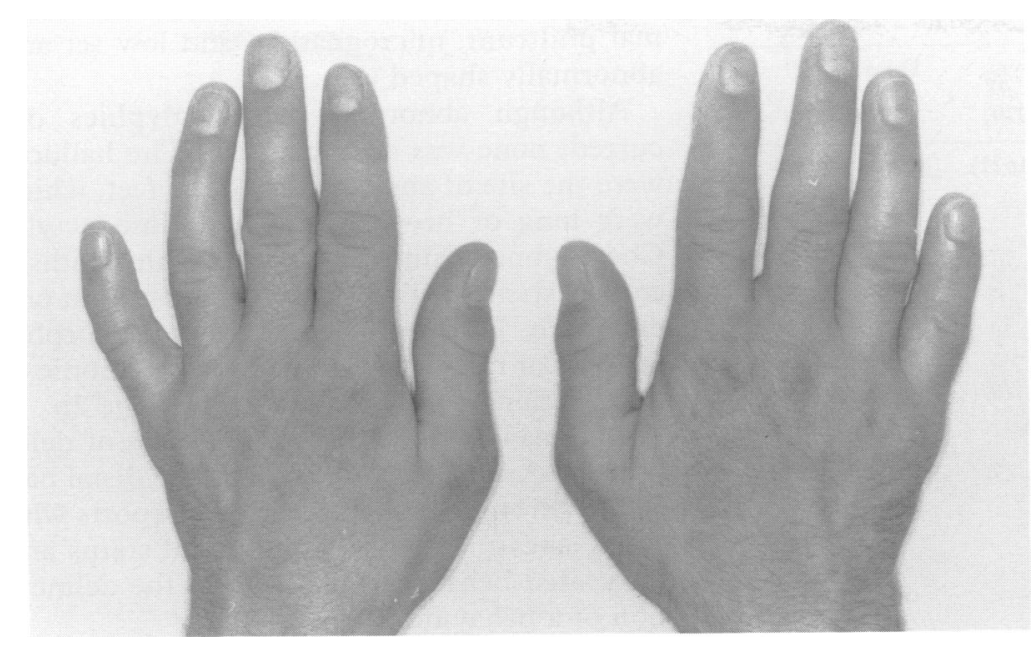

Figure 2 Dorsal view of the hands.

with noticeable facial dysmorphism. He has a narrow, rectangular face, large, protruding, low set ears, minimal blepharophimosis, horizontal palpebral fissures, and a convergent strabismus. He has a pronounced nasal bridge and a broad nose with a well formed philtrum. $\mathrm{He}$ has a high arched palate, several absent upper teeth, and micrognathia. His hair is sparse (fig 1).

His hands are normal in length (total hand length $18.5 \mathrm{~cm}$, middle finger length $8 \mathrm{~cm}$ ) with bilateral short fifth fingers, bilateral fourth finger clinodactyly (fig 2), and finger overlap when he attempts to use the hands. There is partial restriction of movement in all distal interphalangeal joints. Dermatoglyphics on the right are (from the radial side of the hand): whorl, whorl, whorl, radial loop, whorl; on the left (from the radial side of the hand): whorl, whorl, ulnar loop, whorl, radial loop. Three palmar creases are present on both hands.

There are no cardiac, abdominal, or genital abnormalities. His chest is narrow with increased anteroposterior diameter. Neurological evaluation showed reduced visual acuity but otherwise normal cranial nerve function. Power, sensation, and reflexes are

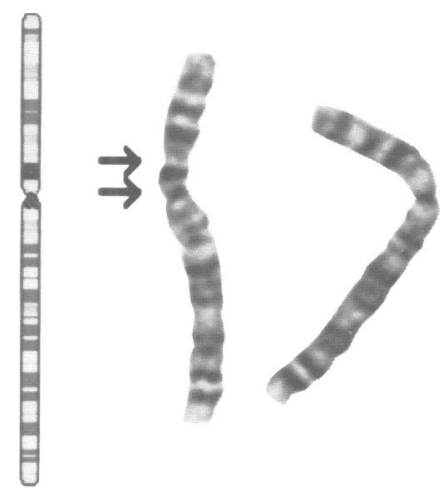

$46, X Y, \operatorname{del}(2)(p 11.2 p 13)$

Figure 3 Karyotype of the proband. normal in all limbs but hypertonia was detected in both legs resulting in a spastic ataxic gait. Full blood count was normal except for a persistent, non-symptomatic, idiopathic thrombocytopenia (platelet counts: $140 \times 10^{9} / 1$ in $1983,122 \times 10^{9} / 1$ in 1985 , and $129 \times 10^{9} / 1$ in 1989 ; normal range 150 to $\left.400 \times 10^{9} / 1\right)$. Biochemical profile and thyroid function tests were normal. Acid phosphatase was normal (the locus for the enzyme acid phosphatase has been assigned to distal $2 \mathrm{p}$ ). Skull $x$ ray was unremarkable but $x$ ray of the hands showed a short middle phalanx of both fifth fingers.

\section{CYTOGENETIC STUDIES}

Cytogenetic studies were performed on stimulated lymphocyte cultures. $G$ banding showed a male karyotype with an interstitial deletion of material in the short arm of one chromosome 2: 46,XY,del(2)(p11.2p13) (fig 3). Therefore the patient is monosomic for part of the short arm of chromosome 2 (band p1 1.2-p13). A cell line from this patient has not been established.

\section{Discussion}

Two cases, by Ferguson-Smith et $a l^{1}$ and by Young et $a l,{ }^{7}$ were excluded from comparison with our case as both had chromosomal abnormalities of other chromosomes as well as the deletion of chromosome 2 . The cases reported by Lundbech and Thogerson ${ }^{8}$ and Gorski et $a l^{9}$ were excluded from comparison as they had deletions of the short and long arms of chromosome 2. Two further cases, by Munke et $a l^{10}$ and Wilson et al, ${ }^{11}$ were also excluded as both patients had holoprosencephaly preventing

Table 1 Clinical findings reported in deletions involving proximal $2 p$.

\begin{tabular}{|c|c|c|c|c|}
\hline & & $\begin{array}{l}\text { Fryns } \\
\text { et al } l^{5} \\
(1979)\end{array}$ & $\begin{array}{l}\text { Duca } \\
\text { et } a l^{6} \\
(1979)\end{array}$ & $\begin{array}{l}\text { Present } \\
\text { case } \\
(1992)\end{array}$ \\
\hline \multicolumn{2}{|c|}{ Breakpoints, del(2) } & $(\mathrm{p} 11 \mathrm{p} 21)$ & (p13p15) & (p11-p13) \\
\hline \multicolumn{2}{|c|}{$\begin{array}{l}\text { Sex } \\
\text { Birth weight }<25 \text { th centile } \\
\text { Birth length }<25 \text { th centile } \\
\text { OFC } \quad<25 \text { th centile } \\
\quad \text { (at birth) }\end{array}$} & $\begin{array}{l}M \\
+ \\
? \\
?\end{array}$ & $\begin{array}{l}\mathrm{F} \\
+ \\
? \\
?\end{array}$ & $\begin{array}{c}M \\
? \\
? \\
?\end{array}$ \\
\hline \multicolumn{2}{|c|}{$\begin{array}{l}\text { Maternal age at birth } \\
\text { Maternal karyotype }\end{array}$} & $\begin{array}{c}25 y \\
?\end{array}$ & $30 \mathrm{y}$ & $?$ \\
\hline \multicolumn{2}{|c|}{$\begin{array}{l}\text { Paternal age at birth } \\
\text { Paternal karyotype } \\
\text { Family history }\end{array}$} & $\begin{array}{c}44 \text { y } \\
- \\
-\end{array}$ & $\begin{array}{l}29 y \\
- \\
-\end{array}$ & $\begin{array}{l}? \\
? \\
?\end{array}$ \\
\hline \multicolumn{2}{|c|}{$\begin{array}{l}\text { Prenatal history } \\
\text { Feeding difficulties } \\
\text { Failure to thrive }\end{array}$} & $\begin{array}{l}? \\
+ \\
+\end{array}$ & $\stackrel{?}{?}$ & $\begin{array}{l}? \\
+ \\
+\end{array}$ \\
\hline \multirow{2}{*}{\multicolumn{2}{|c|}{$\begin{array}{l}\text { Neonatal muscle tone } \\
\text { Delayed closure of } \\
\text { fontanelles } \\
\text { Developmental delay }\end{array}$}} & Hypo & $?$ & $?$ \\
\hline & & $\stackrel{?}{+}$ & $\begin{array}{l}+ \\
+\end{array}$ & $\begin{array}{l}? \\
+\end{array}$ \\
\hline \multirow{2}{*}{$\begin{array}{l}\text { Stature } \\
\text { OFC }\end{array}$} & $\begin{array}{l}=<50 \text { th centile } \\
=<25 \text { th centile }\end{array}$ & $\stackrel{+}{-}$ & $\begin{array}{l}+ \\
+\end{array}$ & $\begin{array}{l}- \\
-\end{array}$ \\
\hline & $\begin{array}{l}=<50 \text { th centile } \\
=<25 \text { th centile }\end{array}$ & $\begin{array}{l}+ \\
+\end{array}$ & - & $\begin{array}{l}+ \\
+\end{array}$ \\
\hline Weight & $\begin{array}{l}=<50 \text { th centile } \\
=<25 \text { th centile }\end{array}$ & $\begin{array}{l}+ \\
+\end{array}$ & $\begin{array}{l}+ \\
+\end{array}$ & - \\
\hline \multicolumn{2}{|c|}{$\begin{array}{l}\text { Mental retardation } \\
\text { Age at report }(y) \\
\text { Age at death }\end{array}$} & $\begin{array}{c}+ \\
14 \\
?\end{array}$ & $\begin{array}{l}+ \\
5 \\
?\end{array}$ & $\begin{array}{c}+ \\
32 \\
\text { Alive }\end{array}$ \\
\hline
\end{tabular}


Table 2 Reported facial dysmorphism and systemic findings in deletions involving proximal $2 p$.

\begin{tabular}{|c|c|c|c|}
\hline & $\begin{array}{l}\text { Fryns } \\
\text { et } a l^{5} \\
(1979)\end{array}$ & $\begin{array}{l}\text { Duca } \\
\text { et } a l^{6} \\
(1981)\end{array}$ & $\begin{array}{l}\text { Present } \\
\text { case } \\
(1992)\end{array}$ \\
\hline Breakpoints, del(2) & $(\mathrm{p} 11 \mathrm{p} 21)$ & (p13p15) & (p11-p13) \\
\hline $\begin{array}{l}\text { Dysmorphic face } \\
\text { Abnormal head shape } \\
\text { Forehead } \\
\text { Prominent } \\
\text { Narrow }\end{array}$ & $\begin{array}{l}+ \\
- \\
- \\
+\end{array}$ & $\begin{array}{l}+ \\
+ \\
- \\
+\end{array}$ & $\begin{array}{l}+ \\
+ \\
- \\
-\end{array}$ \\
\hline $\begin{array}{l}\text { Blepharophimosis } \\
\text { Strabismus }\end{array}$ & $\overline{+}$ & $\overline{+}$ & $\bar{t}$ \\
\hline $\begin{array}{l}\text { Abnormal nasal bridge } \\
\text { Abnormally shaped nose } \\
\text { Abnormal philtrum } \\
\text { Arched palate } \\
\text { Micrognathia }\end{array}$ & $\begin{array}{l}- \\
- \\
- \\
-\end{array}$ & $\begin{array}{l}+ \\
+ \\
+ \\
-\end{array}$ & $\begin{array}{l}+ \\
+ \\
+ \\
+ \\
+\end{array}$ \\
\hline $\begin{array}{l}\text { Low set ears } \\
\text { Abnormal ears } \\
\text { Short neck } \\
\text { Sparse hair }\end{array}$ & $\begin{array}{l}- \\
\overline{+} \\
-\end{array}$ & $\begin{array}{l}+ \\
+ \\
+ \\
-\end{array}$ & $\begin{array}{l}+ \\
+ \\
+ \\
+\end{array}$ \\
\hline $\begin{array}{l}\text { Fingers } \\
\text { Short } \\
\text { Overlapping } \\
\text { Clinodactyly }\end{array}$ & $\begin{array}{l}- \\
- \\
-\end{array}$ & $\begin{array}{l}- \\
- \\
-\end{array}$ & $\begin{array}{l}5 \text { th } \\
+ \\
5 \text { th }\end{array}$ \\
\hline $\begin{array}{l}\text { 5th finger, single flexion } \\
\text { crease } \\
\text { Immobility, }\end{array}$ & - & - & - \\
\hline $\begin{array}{l}\text { Interphalangeal joint } \\
\text { Abnormal dermatoglyphics } \\
\text { Halluces }\end{array}$ & - & - & + \\
\hline Long & $\begin{array}{l}+ \\
+ \\
+\end{array}$ & $\begin{array}{l}+ \\
+ \\
+\end{array}$ & $\begin{array}{l}- \\
-\end{array}$ \\
\hline Overlapping toes & - & + & - \\
\hline $\begin{array}{l}\text { Vertebral anomalies } \\
\text { Chest abnormalities }\end{array}$ & $\begin{array}{l}+ \\
+\end{array}$ & $\begin{array}{l}+ \\
+\end{array}$ & $\bar{t}$ \\
\hline Cryptorchidism & $\begin{array}{l}+ \\
+\end{array}$ & - & - \\
\hline Seizures & - & - & $\begin{array}{l}\text { Past } \\
\text { history }\end{array}$ \\
\hline
\end{tabular}

$+=$ feature present. $-=$ feature absent.

valid behavioural comparison. Comparison of the findings reported by Fryns et $a l^{5}$ and Duca et $a l^{6}$ (table 1) shows no relationship between paternal age, paternal karyotype, family inheritance, or prenatal development and deletion of the proximal part of the short arm of chromosome 2 .

A brief review of case reports (tables 1 and 2) shows a variety of features. Developmental delay and mental retardation were present in all cases, with growth retardation present in all cases except in the present reported case. The facial dysmorphism, present in all cases, consisted of an abnormal shape, often rectangular. Prominence of the forehead was observed in our case and a narrow forehead in two cases. ${ }^{56}$ In general the following abnormalities were found: strabismus, abnormal nasal bridge, abnormally shaped nose, arched palate, abnormal philtrum, micrognathia, and low set and abnormally shaped ears.

Although abnormal dermatoglyphics occurred, none was characteristic. The halluces were the site of abnormality of the feet, which were long or broad or showed clinodactyly. Chest abnormalities occur. Cryptorchidism and spasticity of the legs were reported in one case each. However, none of the dysmorphic features or malformations is pathognomonic of the deletion of the proximal part of the $2 p$.

The majority of the reported cases of deletions of chromosome 2 involved the distal half of the chromosome. Further case reports with serial assessments of psychological status and associated behaviour may lead to the delineation of a behavioural phenotype.

The authors gratefully acknowledge the help given by Professor Hultén, Professor of Cytogenetics, Birmingham University, Birmingham, during the preparation of this paper. Chromosomal analysis was performed by $\mathrm{Ms}$ C T Maliszewska, West Midlands Regional Cytogenetics Unit, Birmingham Maternity Hospital, Edgbaston, Birmingham, UK.

1 Ferguson-Smith MA, Newman BF, Ellis PM, Thomson DMG. Assignment by deletion of human red cell acid phosphatase gene locus to the short arm of chromosome 2. phosphatase gene locus to

2 Zackai E, Emanuel B, Mellman WJ, et al. Deletion of the short arm of chromosome 2 from a subject with congenital anomalies. Cytogenet Cell Genet 1977;18:108.

3 Emanuel BS, Zackai EH, Van Dyke DC, Swallow DM, Allen FH, Mellman WJ. Deletion mapping: further evidence for the location of acid phosphatase (ACP1) within 2p23. Am F Med Genet 1979;4:167-72.

4 Neidich J, Zackai E, Aronson M, Emanuel BS. Deletion of 2p: a cytogenetic and clinical update. Am $\mathcal{f}$ Med Genet 1987;27:707-10

5 Fryns JP, de Waele $P$, Van den Berghe $H$. Interstitial deletion of the short arm of chromosome 2 in a moderately mentally retarded boy without gross clinical stigmata. Hum Genet 1979;51:123-5.

6 Duca D, Ioan D, Meila P, Ionescu-Cerna M, Simionescu L, Maximiliam C. Interstitial deletion (2)(p13p15). Hum Genet 1981;57:214-6.

7 Young RS, Medrano MA, Hansen KL. Partial 2p deletion in a girl with a complex chromosome rearrangement in a girl with a complex chromosome rearrangement
involving chromosomes $2,6,11$, and $21 . \mathcal{J}$ Med Genet

8 Lundbech PE, Thogersen $T$. Unbalanced translocation between chromosomes 2 and 7 with de novo deletion of band 35 on the long arm of chromosome 2. Hum Genet 1989;82:92-3.

9 Gorski JL, Cox BA, Kyine M, Uhlmann W, Glover TW. Terminal deletion of the long arm of chromosome 2 in a mildly dysmorphic hypotonic infant with karyotype 46 , XY,del(2)(q37). Am ₹ Med Genet 1989;32:350-2

10 Munke M, Emanuel BS, Zackai EH. Holoprosencephaly: association with interstitial deletion of $2 \mathrm{p}$ and review of the cytogenetic literature. Am ₹ Med Genet 1988;30:929-

11 Wilson GW, Shanks DE, Sudduth KW, Couper KA, McIlhenny J. Holoprosencephaly and interstitial deletion of 2(p2101p2109). Am ₹ Med Genet 1989;34:252-4. 